Rechtsmedizin 2022 · 32:125-130

https://doi.org/10.1007/s00194-021-00513-5

Accepted: 4 June 2021

Published online: 12 July 2021

(c) The Author(s) 2021

\section{On the handling of German citizens who died abroad}

\section{A presentation and evaluation of the procedure in Hamburg}

\author{
P. Witte $\cdot$ J.-P. Sperhake $\cdot$ K. Püschel ${ }^{1} \cdot$ F. Holz ${ }^{2}$ B. Ondruschka ${ }^{1}$ A. S. Schröder ${ }^{1}$ \\ ${ }^{\prime}$ Institute of Legal Medicine, University Medical Center Hamburg-Eppendorf, Hamburg, Germany \\ ${ }^{2}$ Institute of Legal Medicine, University Hospital Frankfurt, Goethe-University, Frankfurt am Main, \\ Germany
}

\title{
Abstract
}

Background: Decedents who are repatriated to Germany from abroad are not systematically registered nationwide. In Hamburg, in addition to an epidemic hygienic examination, registration and examination of the content of the documents accompanying the corpses of German citizens has been carried out since 2007. In this way, unclear and non-natural deaths in particular are to be followed up as necessary. Material and methods: Protocols of external and internal autopsies of German nationals who died abroad and were repatriated to Hamburg via the port or airport between 2007 and 2018 were retrospectively evaluated with respect to numbers, completeness of the autopsy abroad and correctness of manner and cause of death. Results: Between 2007 and 2018 a total of 703 corpses were repatriated via the port or airport of Hamburg and examined by the Port Medical Service for epidemic hygiene and for anything conspicuous in the documents accompanying the corpse. Of them, 307 corpses were examined at the Institute of Legal Medicine at the University Medical Center Hamburg-Eppendorf. In total, $82.4 \%$ of the examined cases had an incorrect, unspecific or incomplete foreign death certificate. Of the deceased, 238 were subjected to a second external autopsy by a forensic pathologist and 69 deceased were autopsied again or for the first time in Hamburg. It was found that $84 \%$ of the autopsies performed abroad were not performed according to German and European standards. The most common discrepancy was incomplete preparation of the organs. In almost one quarter of the autopsies performed in Hamburg a different cause of death than abroad was determined at autopsy.

Conclusion: Since the quality of autopsies performed abroad sometimes does not meet the standards in Germany and Europe and many papers accompanying corpses are incomplete or incorrectly filled out, a systematic review procedure in the home country is recommended. Through the system established in Hamburg in 2007, at least a re-evaluation of the cases takes place.

\section{Keywords}

International body passport - Cause of death - Manner of death - Repatriation of corpses - Autopsy

\section{Introduction}

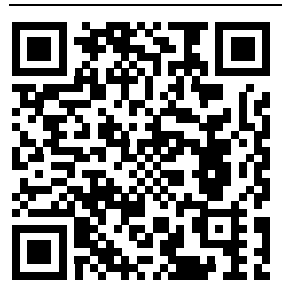

Scan QR code \& read article online
There is no systematic national procedure for dealing with German citizens who have died abroad after the body has been repatriated to Germany. This can be a problem, especially in cases of unclear or non-natural deaths. In Hamburg, in cooperation with the Port Medical Service (PMS), there has been a systematic verification procedure (- Fig. 1) for decedents returned to
Hamburg from abroad via the airport or port since 2007.

Due to globalization and increased mobility, the number of German tourists abroad and German emigrants has been continuously increasing since the end of the last century [1-3]. Due to these developments, people are also increasingly dying outside their home country. A repatriation and burial of the body in the home country is common. For cross-bor- 
German citizen dies abroad. A medical death certificate is issued locally, on the basis of which an international body passport is issued.

The relatives of the deceased assign a German funeral home to transport the body back to Germany.

\section{The funeral home reports the deceased to the PMS if the repatriation of the body is via the port or airport.}

The corpse accompanying papers are inspected by the PMS
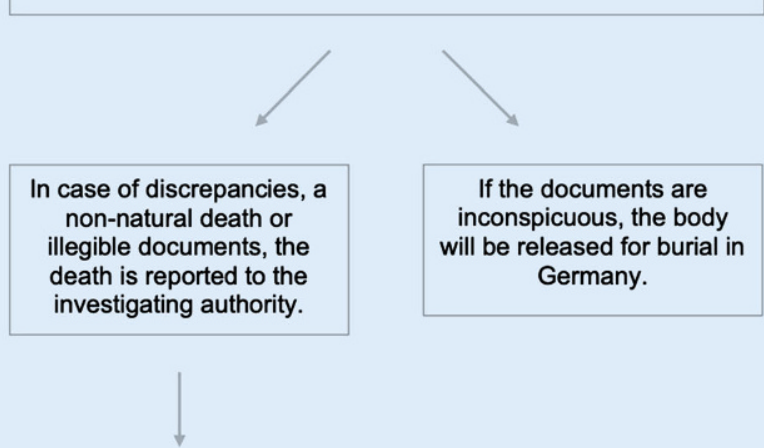

The body is taken to the ILM for a second

postmortem examination;

if necessary, a forensic autopsy is ordered.
Fig. $1<$ Reporting procedure of the model practiced in Hamburg for handling the bodies of German citizens who have died abroad. PMS Port Medical Service, ILM Institute of Legal Medicine Hamburg

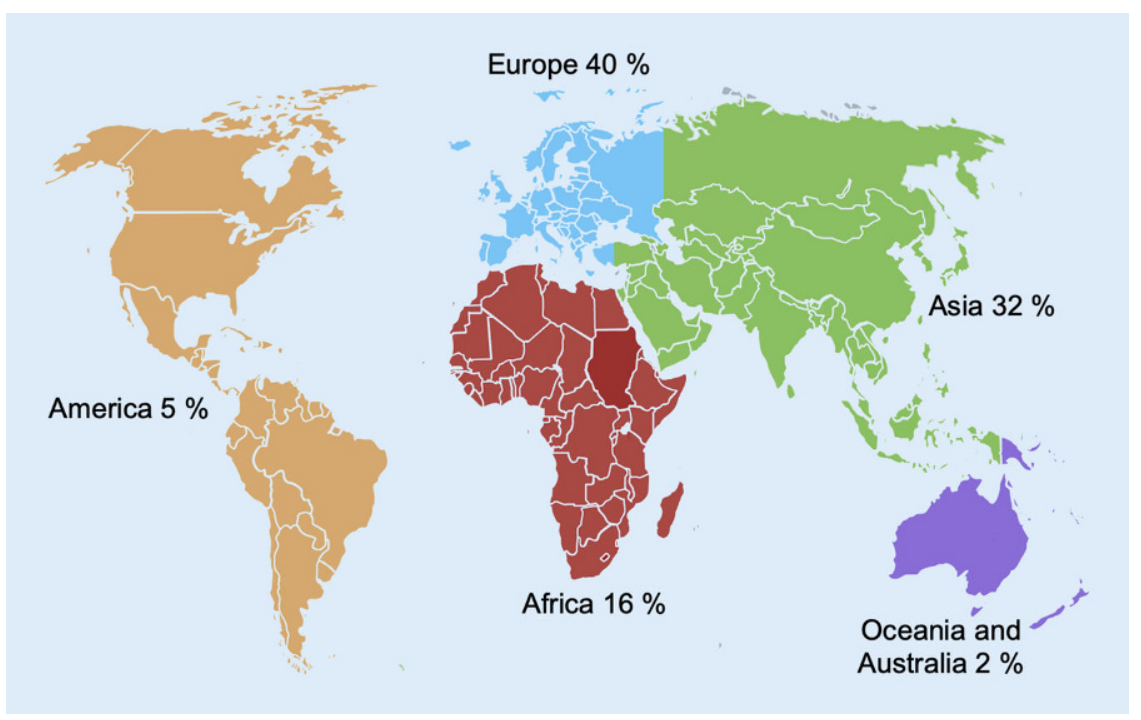

Fig. 2 ム Place of death (continent), not specified:5\%

\section{Infobox 1}

International body passport (Leichenpass, laissez-passer mortuaire) according to information from the Foreign Office [4], the Hamburg Burial Act [5], the Berlin Agreement of 1937 [9] and the Strasbourg Agreement of 1973 (European Agreement of the Transfer of Corpses) [10]

A body passport is required for the international transport of deceased. The basis for this is the International Convention on the Transportation of Corpses from 10 February 1937 [9]. This agreement lays down uniform provisions valid between the member states for the international transport of corpses. The passport issued for this purpose contains the name, age, date of death, place of death and cause of death of the deceased and may only be issued upon presentation of a death certificate (Todesbescheinigung and Sterbeurkunde). If a German citizen dies in a country that has not signed the 1937 agreement or the Strasbourg Agreement of 1973 , the German embassy abroad located in that country shall issue a document similar to the body passport for the repatriation of the body.

der transport of corpses, an international body passport (see info text) is required, for which a medical death certificate issued by physicians in the country of death is mandatory [4]. A further examination of the body by German physicians is not mandatory as the international body passport is considered a death certificate [5]. This also applies in the case of a non-natural death. The responsible investigating authority is not regularly informed about all deaths abroad; therefore, national totals are missing for valid statistics. According to Riemer et al. [6], since 2007 in addition to the epidemic hygiene clarification a formal and contentrelated check of the documents accompanying the corpse of all German citizens repatriated via the port or airport of Hamburg has been carried out by the PMS in Hamburg. In the event of illegible documents, discrepancies or a non-natural manner of death, the PMS sends a report to the responsible state criminal investigation office (LKA). The investigating authorities then often request an external postmortem examination by a forensic pathologist and, in some cases, a forensic autopsy. The results of the external and internal autopsies are communicated to the investigating authorities. 


\begin{tabular}{|c|c|c|c|c|c|}
\hline $\begin{array}{l}\text { Country of } \\
\text { death }\end{array}$ & Deceased & $\begin{array}{l}\text { Deceased with an } \\
\text { external examination } \\
\text { only in Hamburg }\end{array}$ & $\begin{array}{l}\text { Deceased with an au- } \\
\text { topsy in the country of } \\
\text { death and in Hamburg }\end{array}$ & $\begin{array}{l}\text { Deceased with an } \\
\text { autopsy in Hamburg } \\
\text { and no autopsy abroad }\end{array}$ & $\begin{array}{l}\text { Body passports with no or insuf- } \\
\text { ficient information of the cause } \\
\text { and manner of death }\end{array}$ \\
\hline Europe & 121 & 101 & 6 & 14 & 74 \\
\hline Spain & 49 & 39 & 4 & 6 & 30 \\
\hline Greece & 20 & 19 & 1 & 0 & 9 \\
\hline Portugal & 11 & 10 & 1 & 0 & 8 \\
\hline France & 11 & 8 & 0 & 3 & 6 \\
\hline Italia & 6 & 6 & 0 & 0 & 4 \\
\hline $\begin{array}{l}\text { United King- } \\
\text { dom }\end{array}$ & 6 & 6 & 0 & 0 & 4 \\
\hline Bulgaria & 5 & 4 & 0 & 1 & 3 \\
\hline Norway & 4 & 3 & 0 & 1 & 3 \\
\hline Switzerland & 2 & 2 & 0 & 0 & 2 \\
\hline Malta & 2 & 2 & 0 & 0 & 2 \\
\hline Cyprus & 1 & 1 & 0 & 0 & 1 \\
\hline Ukraine & 1 & 1 & 0 & 0 & 0 \\
\hline Austria & 1 & 0 & 0 & 1 & 0 \\
\hline Sweden & 1 & 0 & 0 & 1 & 1 \\
\hline Croatia & 1 & 0 & 0 & 1 & 0 \\
\hline
\end{tabular}

Table 2 Autopsies abroad and in Hamburg

\begin{tabular}{|l|l|l|l|}
\hline & $\begin{array}{l}\text { Total } \\
(n=307)\end{array}$ & $\begin{array}{l}\text { Autopsy in Ham- } \\
\text { burg }(n=69)\end{array}$ & $\begin{array}{l}\text { External examination in Hamburg/no } \\
\text { autopsy in Hamburg }(n=238)\end{array}$ \\
\hline $\begin{array}{l}\text { Autopsy } \\
\text { abroad }\end{array}$ & $173(56.4 \%)$ & $25(36.2 \%)$ & $148(62.2 \%)$ \\
\hline $\begin{array}{l}\text { No autopsy } \\
\text { abroad }\end{array}$ & $134(43.6 \%)$ & $44(63.8 \%)$ & $90(37.8 \%)$ \\
\hline
\end{tabular}

\section{Methods}

A retrospective evaluation of all cases of German citizens who died abroad and were examined at the Institute of Legal Medicine (ILM) in Hamburg between 2007 and 2018 (external examination or autopsy) was performed. Cases were assigned via a keyword search in the ILM electronic database using the following search terms: "tissue fixation", "embalming", "airport", "hotel", "port", "vacation", "body passport", "foreign country", "repatriation", "body transport certificate", "ship", "airplane". The cases known in the ILM were then matched against the PMS reporting lists for that period, and missing cases were added to the search in the ILM electronic database. For all cases, external examination records and autopsy protocols from the ILM were evaluated with respect to the following parameters: year of death, place of death, age of the deceased, time interval between death (abroad) and examination at the ILM (in Germany), autopsies abroad, and autop- sies in Hamburg. Where the information was available, the manner of death indicated on the papers accompanying the corpse was compared with the manner of death determined by the examination at the ILM (external examination or autopsy). In the case of an autopsy performed abroad and a second autopsy performed in the ILM, the completeness of the autopsy performed abroad was assessed, and a comparison was made between the cause of death determined abroad and that determined in the ILM. The evaluation was based on the autopsy guidelines of the German Society of Legal Medicine (DGRM) [7] and the Harmonization of Medicolegal Autopsy Rules of the European Council of Legal Medicine (ECLM, e.g., opening of all three body cavities and examination of all organs) [8]. Data were tabulated and descriptively analyzed.

\section{Results}

\section{Study collective}

Between 2007 and 2018, a total of 703 German nationals who died abroad were repatriated via the port or airport of Hamburg (excluding foreign cremations) and their documents were examined by the PMS. In total, 301 cases were reported to the LKA in Hamburg and 307 bodies were examined at the ILM, in 6 cases a forensic medical examination was ordered by other means (e.g. privately). This corresponds to an annual average of 26 Germans who died abroad and were examined at the ILM (range 11-40 cases per year). The average age of the persons examined was 54.2 years (range fetus-93 years). The gender distribution was $73 \%$ male and $27 \%$ female.

\section{Repatriation}

Repatriation occurred from all five habitable continents (North and South America combined as America) (- Fig. 2) and 40\% of the deceased came from an European country (-Table 1). Of these, most deceased came from Spain (49 deceased). This was followed by Greece (20), Portugal and France (11 each), the United Kingdom and Italy (6 each), Bulgaria (5), 
Table 3 Details on the techniques used in autopsies abroad (multiple entries possible)

\begin{tabular}{|l|l|l|l|l|l|}
\hline & $\begin{array}{l}\text { Complete preparation of } \\
\text { organs }\end{array}$ & $\begin{array}{l}\text { Opening of the head } \\
\text { cavity }\end{array}$ & $\begin{array}{l}\text { Opening of the thoracic cavi- } \\
\text { ties }\end{array}$ & $\begin{array}{l}\text { Opening of the abdominal } \\
\text { cavity }\end{array}$ & $\begin{array}{l}\text { Neck prepara- } \\
\text { tion }\end{array}$ \\
\hline Yes & $4(16 \%)$ & $22(88 \%)$ & $25(100 \%)$ & $25(100 \%)$ & $13(52 \%)$ \\
\hline No & $21(84 \%)$ & $3(12 \%)$ & $0(0 \%)$ & $0(0 \%)$ & $12(48 \%)$ \\
\hline
\end{tabular}

\begin{tabular}{|l|l|l|l|}
\hline \multicolumn{4}{|c|}{ Table 4 Final results on the causes of death determined abroad and in Hamburg } \\
\hline $\begin{array}{l}\text { Change in } \\
\text { cause of } \\
\text { death }\end{array}$ & $\begin{array}{l}\text { All cases with au- } \\
\text { topsy in Hamburg } \\
(n=69)\end{array}$ & $\begin{array}{l}\text { Cases with autopsy } \\
\text { abroad and in Ham- } \\
\text { burg }(n=25)\end{array}$ & $\begin{array}{l}\text { Cases without autopsy } \\
\text { abroad but autopsy in Ham- } \\
\text { burg }(n=44)\end{array}$ \\
\hline Yes & $16(23.2 \%)$ & $0(0 \%)$ & $16(36.4 \%)$ \\
\hline No & $12(17.4 \%)$ & $7(28 \%)$ & $5(11.4 \%)$ \\
\hline $\begin{array}{l}\text { Not speci- } \\
\text { fied }\end{array}$ & $41(59.4 \%)$ & $18(72 \%)$ & $23(52.2 \%)$ \\
\hline
\end{tabular}

and Norway (4). One or two deceased each came from Croatia, Sweden, Austria, Switzerland, Cyprus, Malta and Ukraine. On average, the interval between death abroad and examination at the ILM in Hamburg was 16 days (range $2-188$ days, median 11 days).

\section{Autopsies}

Of the 307 deceased examined in the ILM 173 (56.4\%) had been autopsied abroad. Of the 307 deceased 69 were autopsied in Hamburg ( 63 on behalf of the investigating authorities and 6 at the request of insurance companies or private individuals), of these, 44 were autopsied only in Hamburg and 25 were autopsied both abroad and in Hamburg (-Table 2). Of the 69 decedents who underwent autopsies at the ILM in Hamburg, 20 came from other European countries, the majority from Spain (10 decedents). Thus, a total of 217 of the 307 German citizens examined who died abroad were autopsied. This corresponds to an autopsy rate of approximately $71 \%$ for the cases with a forensic medical examination in Hamburg. The overall autopsy rate from all persons who died abroad is not known.

For the 25 cases with autopsy abroad and in Hamburg, the quality of the autopsy abroad was assessed using the standards of the DGRM and the ECLM (• Table 3). In $84 \%$ of the cases, the autopsy performed abroad did not fully comply with the standards of the DGRM or the ECLM: In 21 cases, the organ preparation was incomplete, in about half of the cases the neck had not been dissected, and in three cases the head cavity had not been opened. In contrast, the abdominal and thoracic cavities had been opened in all autopsies performed abroad. None of the autopsies performed abroad had dissected arms, legs, or back. Results of a blood alcohol concentration determination and/or a chemical toxicological examination were not available for any of the autopsy cases abroad. In Hamburg, these were performed in 14 of 69 autopsies of which 9 cases had already been autopsied abroad. Of the 14 tests four showed abnormal findings (methanol intoxication, heroin intoxication, intoxication with tricyclic antidepressants, and in one case with moderate alcohol concentration). Of six deceased from European countries (four from Spain, one from Portugal, one from Greece) with an autopsy in the country of death and in Hamburg, two met the DGRM and ECLM standard.

\section{Cause and manner of death}

Of 307 cases examined 253 (82.4\%) had an incorrectly or incompletely issued foreign certificate. The majority of cases (41 of 69 with autopsy at the ILM) could not be compared conclusively with respect to cause of death because there was insufficient information on the cause of death determined abroad (31 cases) or no clear cause of death could be determined in Hamburg (10 cases) (- Table 4). Among the 121 deceased from other European countries, information on the cause of death was missing from the death certificates in 74 cases. In 10 of these cases, a second autopsy was performed in Hamburg in addition to the second external postmortem examination. Among all the autopsy cases that could be compared, there were five cases in which a natural manner of death was indicated and a non-natural death was determined after the examination in Germany.

Particularly concise non-natural deaths are shown in $\mathbf{0}$ Table 5.

\section{Discussion}

In Germany, as in some other countries, there is no systematic recording of citizens who died abroad by the registration authorities. In the USA, however, all nonnatural deaths of U.S. citizens abroad are recorded by the authorities by country and date of death [11, 12]. Hamburg is the only state in Germany that systematically records at least the deceased repatriated to Hamburg by ship and plane through the system for verification of Germans who died abroad, which was introduced in 2007. In contrast, German citizens who died abroad and were repatriated by land are not systematically recorded in any federal state.

The majority of the documents accompanying the corpse examined in the ILM did not contain verifiable information on the manner and/or cause of death. Comparable studies from Hamburg [6], Great Britain [13, 14], and Frankfurt (Germany) [15] already indicated a lack of completeness of the documents. This could be due to incomplete recording of type and cause of death in some countries, as stated in a World Health Organization (WHO) report [16]; however, no corresponding legislative changes have yet been initiated neither nationally nor globally.

Partially incorrect assessment of the manner of death, as demonstrated in at least five cases in the present study, has already been pointed out in previous studies $[6,15]$. Overall, in the present study population, 253 of 307 cases examined (82.4\%) had an incorrectly, unspecifically or incompletely completed certificate from abroad. 
Table 5 Exemplified cases of non-natural deaths abroad

\begin{tabular}{|l|l|l|l|l|l|}
\hline Case & $\begin{array}{l}\text { Place of } \\
\text { death } \\
\text { (country) }\end{array}$ & $\begin{array}{l}\text { Age } \\
\text { (years) }\end{array}$ & $\begin{array}{l}\text { Autopsy } \\
\text { abroad }\end{array}$ & $\begin{array}{l}\text { Assumed cause of death } \\
\text { (information from the } \\
\text { body passport) }\end{array}$ & $\begin{array}{l}\text { Autopsy cause of } \\
\text { death (Hamburg) }\end{array}$ \\
\hline 1 & Austria & 57 & No & Pulmonary embolism & Drowning \\
\hline 2 & Peru & 70 & Yes & Not specified & $\begin{array}{l}\text { Hemorrhagic shock } \\
\text { from gunshot injury }\end{array}$ \\
\hline 3 & $\begin{array}{l}\text { United Arab } \\
\text { Emirates }\end{array}$ & 55 & Yes & Not specified & $\begin{array}{l}\text { Craniocerebral } \\
\text { trauma in motocross } \\
\text { accident }\end{array}$ \\
\hline 4 & Turkey & 21 & Yes & Not specified & Methanol intoxication \\
\hline 5 & Vietnam & 23 & No & Myocardial infarction & Heroin intoxication \\
\hline
\end{tabular}

Of these 253 cases 74 were from a European country. This calls into question the status of the international body passport as a death certificate. The autopsy rate among Germans who died abroad in the respective country of death was surprisingly high (approx. 56\% for all deceased with subsequent forensic medical examination in Hamburg). Whether this rate is so high only among German nationals or also among domestic decedents in the respective country cannot be judged for lack of publicly available data; however, in the cases that were autopsied abroad and in Hamburg, an incomplete autopsy was evident in $84 \%$ of the cases, measured at least by German and European standards; in most cases, the organs had not been completely dissected. The presented results are in agreement with previous studies from Wales [13] and Frankfurt (Germany) [15]. On this rationale, it seems reasonable to strive for a second autopsy on German soil at least for non-natural or unexplained deaths from abroad and for deaths with incomplete records. Postmortem computed tomography (PMCT) could also provide initial results on relevant pathologies as well as on the completeness of the autopsy performed abroad, contrary to the current catalogue of indications, and thus serve as a decision-making aid for a (potentially necessary) second autopsy [17].

In 16 cases the examination in Hamburg revealed a cause of death different from that provided from abroad, both in the external postmortem examination and in the autopsy result. It can be assumed that the actual number may have been even higher, since in many cases no valid comparison was possible due to incomplete information from abroad. Furthermore, it can be assumed that the number of wrong causes of death might have been falsely too low due to the low number of autopsies in Hamburg; however, the present results demonstrate the legitimacy of the Hamburg system for dealing with German citizens who died abroad and should be used for policy decisions in other metropolitan regions or states in Germany. The results of other studies $[13,15,18]$ also confirmed that the cause of death recorded in the international body passport does not always correspond to the actual cause of death.

\section{Conclusion}

Regarding the quality and quantity of autopsies, Germany is certainly not the gold standard worldwide; however, there are general, also internationally recognized standards to which the pathological and forensic medical institutes in Germany adhere. Since autopsies performed abroad in a relevant number of cases do not meet the standards applied in Germany and papers accompanying corpses are often incomplete or incorrectly filled out, the verification procedure introduced in Hamburg in 2007 is also recommended for other federal states and regions with corresponding ports or airports. In addition, a nationwide registration register for deaths abroad would appear to make sense in order to identify deceased persons who are repatriated by land. This also applies to deceased who have already been cremated abroad. Furthermore, the status of the international body passport as a death certificate appears questionable.
Corresponding address

PD Dr. med. A. S. Schröder

Institute of Legal Medicine, University Medical Center Hamburg-Eppendorf Butenfeld 34, 22529 Hamburg, Germany as.schroeder@uke.de

Funding. Open Access funding enabled and organized by Projekt DEAL.

\section{Declarations}

Conflict of interest. P. Witte, J.-P. Sperhake, K. Püschel, F. Holz, B. Ondruschka and A. S. Schröder declare that they have no competing interests. Ethical standards. For this article no studies with human participants or animals were performed by any of the authors. All studies mentioned were in accordance with the ethical standards indicated in each case. Ethical approval: an ethical approval was waived due to the retrospective and descriptive nature of the study.

Open Access. This article is licensed under a Creative Commons Attribution 4.0 International License, which permits use, sharing, adaptation, distribution and reproduction in any medium or format, as long as you give appropriate credit to the original author(s) and the source, provide a link to the Creative Commons licence, and indicate if changes were made. The images or other third party material in this article are included in the article's Creative Commons licence, unless indicated otherwise in a credit line to the material. If material is not included in the article's Creative Commons licence and your intended use is not permitted by statutory regulation or exceeds the permitted use, you will need to obtain permission directly from the copyright holder. To view a copy of this licence, visit http://creativecommons.org/licenses/by/4.0/.

\section{References}

1. Stölch A (1995) Entwicklung des modernen Tourismus (ab 18. Jahrhundert) in Europa. http://www.wirtschaftsgeografie. com/Tourismus/Entwicklung_Tourismus/body_ entwicklung_tourismus.html. Accessed 11 Mar 2021

2. Statista (2018) Reiseverhalten der Deutschen Dossier. https:/de.statista.com/statistik/ studie/id/13611/dokument/reiseverhalten-derdeutschen-statista-dossier. Accessed 11 Mar 2021

3. Reinhardt U (2018) Tourismus Analyse 2018. http://www.tourismusanalyse.de/fileadmin/ user_upload/tourismusanalyse/2018/Stiftungfuer-Zukunftsfragen-Tourismusanalyse-2018. pdf. Accessed 11 Mar 2021 (Stiftung für Zukunftsfragen, Hamburg)

4. Auswärtiges Amt (2019) Hilfe für Deutsche in Notfällen im Ausland, Vermissten- und Todesfälle. https://www.auswaertiges-amt.de/de/service/ konsularinfo/hilfe-notfaelle. Accessed $11 \mathrm{Mar}$ 2021

5. Freie und Hansestadt Hamburg Behörde für Justiz und Verbraucherschutz (2019) Hamburger Gesetz über das Leichen-, Bestattungs- und 


\section{Original reports}

Friedhofswesen (Bestattungsgesetz) vom 30.10.2019, § 8 Abs. 2. http://www.landes recht-hamburg.de/jportal/portal/page/bsha prod.psml;jsessionid=F96C9F4ACACDDB7C9CB7 F3F124F369D5.jp14? showdoccase $=1 \&$ doc.id $=j$ lr BestattGHA2020rahmen. Accessed 11 Mar 2021

6. Riemer T, Püschel K, Schlaich C (2012) Grenzüberschreitende Rückführung von Auslandstoten Umgang der Gesundheitsbehörde mit nichtnatürlichen und unaufgeklärten Todesfällen. Rechtsmedizin 22:31-38

7. Deutsche Gesellschaft für Rechtsmedizin (2018) S1-Leitlinie für die rechtsmedizinische Leicheneröffnung. AWMF-Online, 054001 (Stand 10/2017). https://www.awmf. org/uploads/tx_szleitlinien/054-001I_S1_Dierechtsmedizinische_Leichenoeffnung_2018-02. pdf. Accessed 11 Mar 2021

8. European Council of Legal Medicine (2014) Harmonisation of medico-legal autopsy (protocol), ECLM update of the principles and rules relating to medico-legal autopsy procedures. http://development. fullscreen.pt/eclm/client/files/0000000001/ eclmharmonisationofautopsyrules2014_70.pdf. Accessed 11 Mar 2021

9. Auswärtiges Amt (1938) Internationales Abkommen für die Leichenbeförderung, RGBI. II S. 199. https://www.auswaertiges-amt.de/blob/ 248444/db12fd9011dcd9dfded7fe14eda56acb/ vertragstextoriginal-data.pdf. Accessed 11 Mar 2021

10. Council of Europe (1973) European agreement on the transfer of corpses (Strasbourg agreement of 1973), ETS no.080. https://www.coe.int/ en/web/conventions/full-list/-/conventions/rms/ 090000168007617d. Accessed 11 Mar 2021

11. Tonellato DJ, Guse CE, Hargarten SW (2009) Injury deaths of US citizens abroad: new data source, old travel problem. J Travel Med 16:304-310

12. U.S. Department of State (2021) U.S. citizen death overseas. https://travel.state.gov/content/travel/ en/international-travel/while-abroad/deathabroad1/death-statistics.html. Accessed 11 Mar 2021

13. Williams EJ, Davison A (2014) Autopsy findings in bodies repatriated to the UK. Med Sci Law 54:139-150

14. Leadbeatter S (1991) Deaths of British nationals abroad - a 10-year survey. Forensic Sci Int 49:103-111

15. Holz F, Saulich MF, Schröder AS, Birngruber CG, Verhoff MA, Plenzig S (2020) Death abroad: medico-legal autopsy results of repatriated corpses: a retrospective analysis of cases at the Department of Legal Medicine in Frankfurt am Main. Forensic Sci Int 310:110257

16. WHO (2010) Bulletin of the World Health Organization. https://www.who.int/bulletin/volumes/88/ 11/09-068809/en/. Accessed 11 Mar 2021

17. Fischer H, Heinemann A (2016) Arbeitsgemeinschaft für Forensische Bildgebung der Deutschen Gesellschaft für Rechtsmedizin. Grundlagen der postmortalen Computertomographie (PMCT) für forensisch-radiologische Anwendungen - Empfehlungen und Indikationskatalog. Rechtsmedizin 26:284-290

18. Bratzke H (1977) Todesfälle von Bürgern der Bundesrepublik Deutschland im Ausland. Arch Kriminol 159:97-106

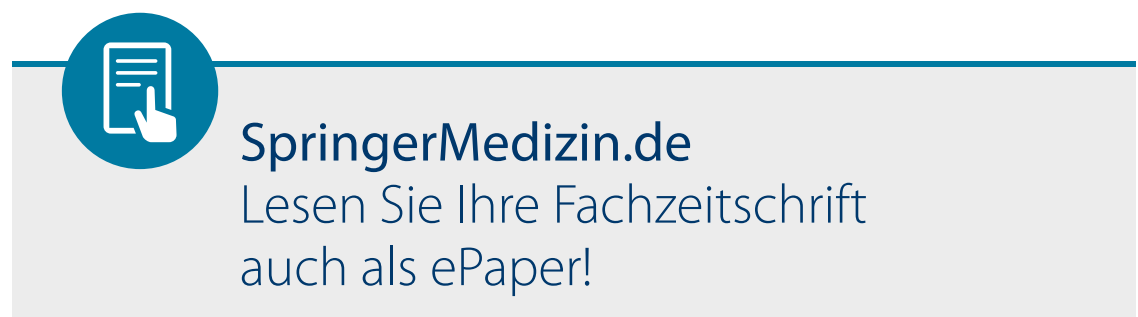

Als Abonnent können Sie Ihre Zeitschrift in verschiedenen Formaten lesen. Wählen Sie je nach Vorliebe und Situation aus, ob Sie die Zeitschrift als PrintAusgabe, in Form von einzelnen Beiträgen auf springermedizin.de oder aber als komplette, elektronische ePaper-Ausgabe lesen möchten.

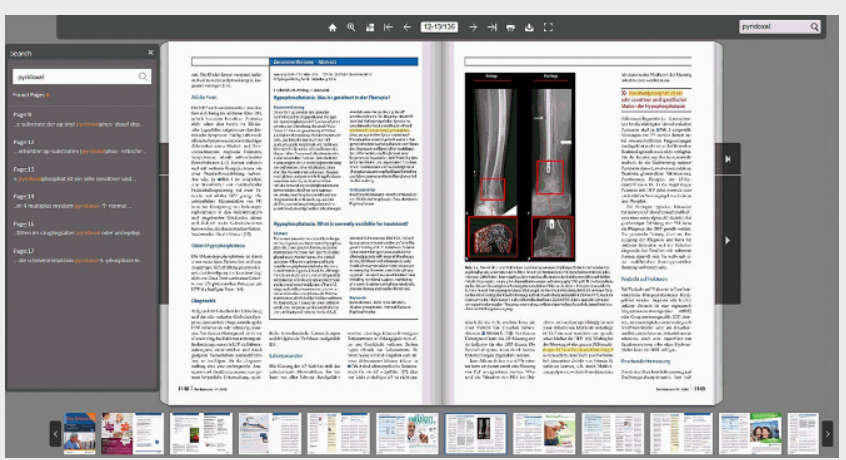

Die ePaper sind die identische Form der gedruckten Ausgaben. Sie sind nutzbar auf verschiedenen Endgeräten wie PC, Tablet oder Smartphone

\section{Das sind die Vorteile des ePapers:}

> Das verlinkte Inhaltsverzeichnis führt Sie direkt zum gewünschten Beitrag.

$>$ Eine Suchfunktion ermöglicht das Auffinden von Schlagworten innerhalb der Zeitschrift.

$>$ Jede Ausgabe kann als PDF heruntergeladen und damit auch offline gelesen werden bzw. auch gespeichert oder ausgedruckt werden.

> Als Abonnent haben Sie Zugang zu allen ePaper-Ausgaben ab 2016.

Sie finden die ePaper auf SpringerMedizin.de bei der jeweiligen Ausgabe Ihrer Fachzeitschrift. Klicken Sie auf den Button „Ausgabe als ePaper lesen“. 